\title{
Plowshare Sequential Device Test
}

\author{
L. B. Ballou
}

\section{MASTER}

RECEIVED

\author{
JAN 311997 \\ OSTI
}

August 2, 1971

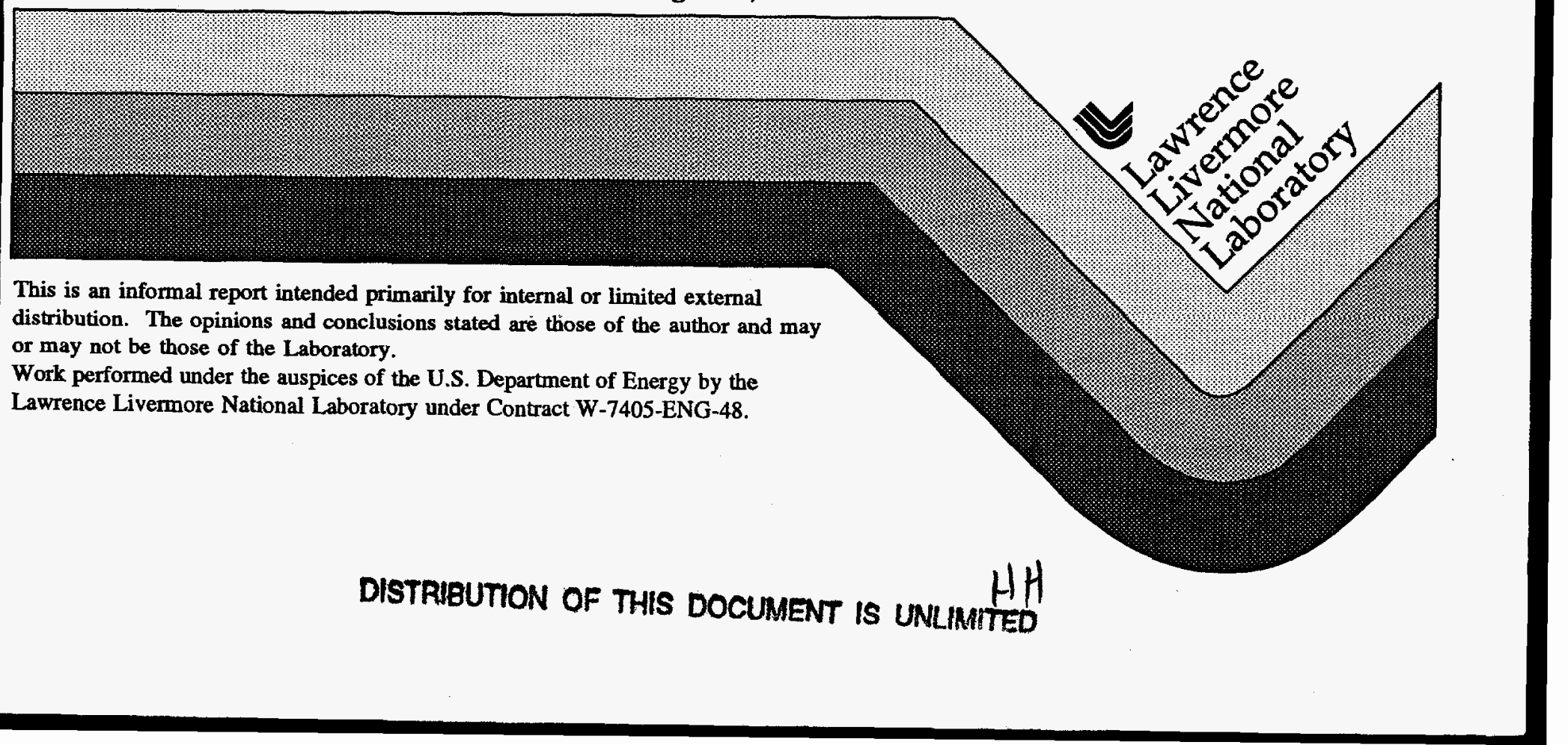




\section{DISCLAIMER}

This report was prepared as an account of work sponsored by an agency of the United States Government. Neither the United States Government nor any agency thereof, nor any of their employees, make any warranty, express or implied, or assumes any legal liability or responsibility for the accuracy, completeness, or usefulness of any information, apparatus, product, or process disclosed, or represents that its use would not infringe privately owned rights. Reference herein to any specific commercial product, process, or service by trade name, trademark, manufacturer, or otherwise does not necessarily constitute or imply its endorsement, recommendation, or favoring by the United States Government or any agency thereof. The views and opinions of authors expressed herein do not necessarily state or reflect those of the United States Government or any agency thereof. 


\section{DISCLAIMER}

Portions of this document may be illegible in electronic image products. Images are produced from the best available original document. 


\section{Specific Objectives}

The specific objective for this test js to demonstrate the adequacy of a ruggedized design of the Diamond explosive for use in a Wagon Wheel project. That project as defined here consists of 4 each 100-kt explosives at spacings $27.5 \mathrm{Rc}$ at a median depth of $\sim 10,000 \mathrm{ft}$ in the Wagon wheel $\|_{1} 1$ hole of E1 Paso Natural Gas. The bottomhole pressure (@ 11,600 ft) is about 8000 psi and the maximum temperature is about $225^{\circ} \mathrm{F}$. Note that the spacing indicated is greater than that proposed by EPNG but consistent with the LLL recomendations. For the purposes of this test, sequential is defined as 10 minutes between detonations.

\section{Experimental Plan}

The proposed test is a "tandem" geometry with a reliable (tested) 20-kt "source" located at the bottom of a $2000 \mathrm{ft}$ deep hole in Area 15 granite. The test device is located about $350 \mathrm{ft}$ above the source and is contained in a section of $103 / 4$ inch casing (like Wagon Wheel 非). The design yield of the test device is 50-kt. Included with the device is appropriate dynamic instrumentation to document the motions and overpressures experienced by the test assembly prior to detonation. The test device will be subjected to the Wagon Wheel environment by pressurizing and heating the $103 / 4$ casing simultaneously to simulate the deep emplacement sequence. The casing will be cemented in place to simulate the coupling to the rock. Obviously, an operational explosive cooling system is required.

The acquisition of prompt reaction-history diagnostics (without developing a "rugged" diagnostic system) on the test device may be limited to " 0 . Krausetype" measurements on a rugged coax cable near the device. Failure diagnostics are probably very hard to get.

$L B B: s b_{j}$

\section{Distribution:}
W. Arnold
o. Krause
T. Barlow
A. Lundberg
J. Behne/R. Guido
R. Seilheimer/R. Stock
G. Broadman
R. Terhune
P. Coyle
J. Toman
J. Cramer
G. Werth
K. Froeschner
R. Woodruff
C. Groseclose
C. Selvage/M. Jones
A. Holzer
F. Johansen/D. Shikany

P.S. The Classification Office can't decide whether this memo is or isn't, so while they make up their mind please treat as CRD. 


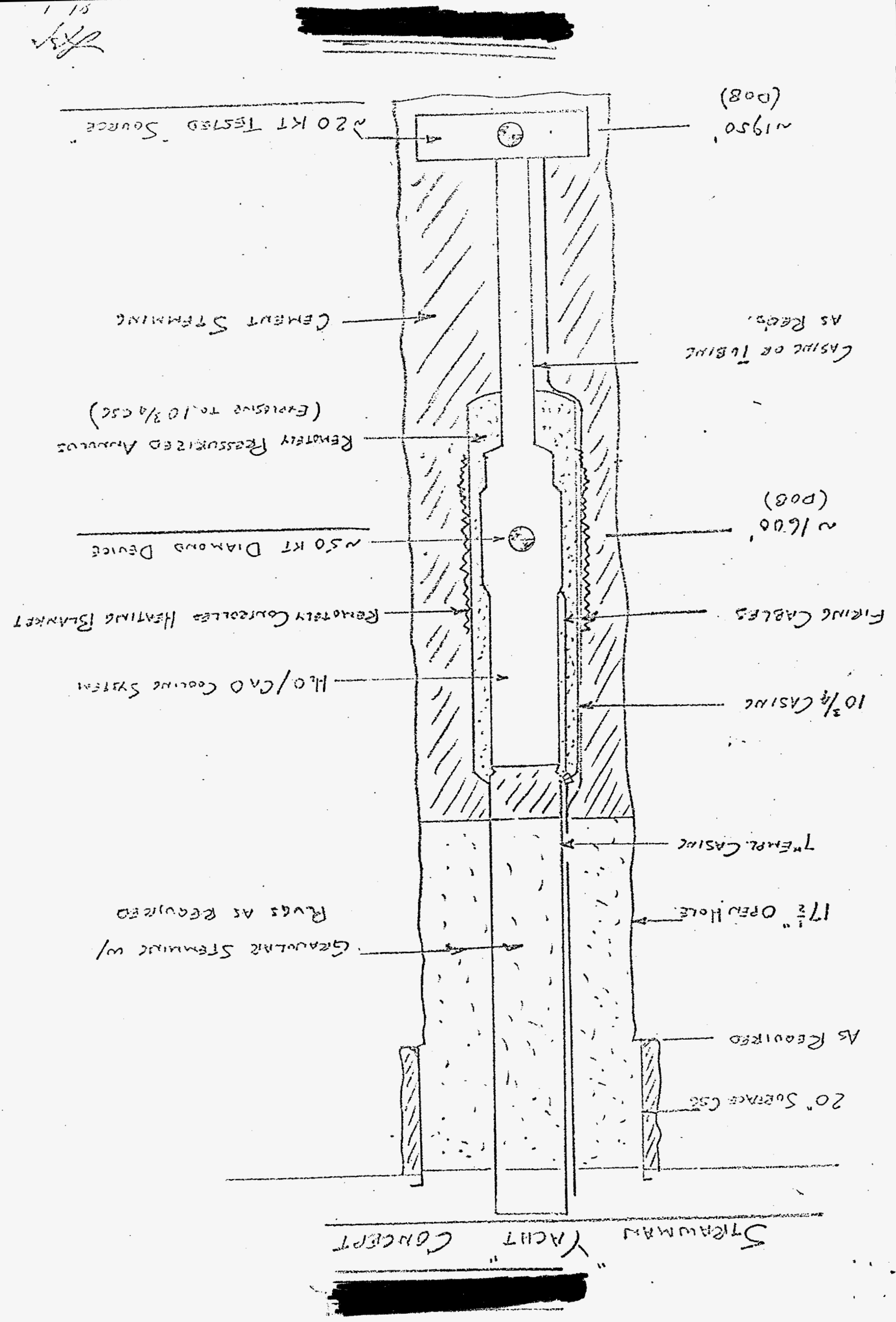

